Kaganga : Jurnal Pendidikan Sejarah dan Riset Sosial Humaniora

Volume 2, Nomor 1, Juni 2019

e-ISSN : 2598-4934

$p-I S S N$ : 2621-119X

DOI : https://doi.org/10.31539/kaganga.v2i1.703

\title{
PENINGKATAN KEMAMPUAN PENGENALAN SEJARAH BUDAYA MINANGKABAU MELALUI LAGU KREASI MINANGKABAU BAGI ANAK USIA DINI
}

\author{
Vivi Anggraini ${ }^{1}$, Adi Priyanto ${ }^{2}$ \\ STKIP Yayasan Abdi Pendidikan Payakumbuh ${ }^{1,2}$ \\ vivianggraini@fip.unp.ac.id ${ }^{1}$
}

\begin{abstract}
ABSTRAK
Penelitian ini bertujuan untuk mendeskripsikan proses dan hasil pembelajaran mengenai lagu kreasi minangkabau untuk menstimulasi pengenalan sejarah budaya minangkabau bagi anak di taman kanak-kanak usia 5-6 tahun. Penelitian ini menggunakan penelitian action reseach pada kelompok B di TK Nurul Hidayah Sumatera Barat. Metode yang digunakan adalah metode Kemmis dan Taggart yang terdiri dari perencanaan, tindakan, observasi, dan refleksi. Teknik pengumpulan data yang digunakan adalah observasi, wawancara, catatan lapangan, instrumen pemantau tindakan dan dokumentasi. Analisis data disajikan secara kuantitatif dan kualitatif. Hasil data secara kuantitatif menunjukan bahwa kemampuan pengenalan sejarah anak dapat meningkat setelah dilakukan tindakan melalui lagu kreasi minangkabau. Hal ini dapat dilihat dari hasil penelitian yang menyebutkan bahwa rata-rata kelas pada pra tindakan sebesar 54\%. Setelah dilakukan tindakan dalam siklus I meningkat rata-rata kelas menjadi 69,70\% dan siklus II meningkat sebesar $82,74 \%$. Dari hasil penelitian ini maka dapat disimpulkan lagu kreasi minangkabau mampu meningkatka kemampuan mengenal sejarah sejarah budaya daerah minangkabau.
\end{abstract}

Kata Kunci : Sejarah Budaya Minangkabau, Lagu Kreasi Minangkabau

\begin{abstract}
This study aims to describe the process and learning outcomes of Minangkabau creation songs to stimulate the introduction of the history of Minangkabau culture for children in kindergarten aged 5-6 years. This study uses action research in group B in TK Nurul Hidayah, West Sumatra. The method used is the Kemmis and Taggart method which consists of planning, action, observation, and reflection. Data collection techniques used were observation, interviews, field notes, action monitoring instruments and documentation. Data analysis is presented quantitatively and qualitatively. The results of quantitative data show that the ability to recognize children's history can increase after action is taken through Minangkabau creation songs. This can be seen from the results of the study which stated that the class average at pre-action was 54\%. After the action in the first cycle, the class average increased to $69.70 \%$ and the second cycle increased by $82.74 \%$. From the results of this study, it can be concluded that Minangkabau creation songs are able to increase the ability to recognize the historical history of the Minangkabau region.
\end{abstract}

Keywords: History of Minangkabau Culture and Minangkabau Creation Songs 


\section{PENDAHULUAN}

Dunia pendidikan sekarang ini, peranan guru bukan hanya sekedar mengajar tetapi meningkat menjadi direktur belajar (director of learning). Artinya, setiap guru diharapkan mampu untuk mengarahkan dan meningkatkan minat dan kebiasaaan dalam kegiatan belajar siswa agar tercapai keberhasilan belajar (kinerja akademik) sebagaimana yang telah ditetapkan dalam sasaran kegiatan proses belajar mengajar. Kelas yang ideal, siswa bekerja dalam kelompok kecil atau bekerja mandiri, dalam rangka mempelajari teori dan contoh, mengerjakan tugas-tugas, menggunakan alat-alat bantu, alat komputasi seperti kalkulator atau komputer, mencari atau memilih pustaka dan mempelajarinya. Siswa dalam bekerja itu diharapkan bertukar pikiran dengan sesama siswa atau bertukar pikiran dengan guru, dan mencatat hal-hal penting yang diperbuat atau diperolehnya. Guru diharapkan dapat mengajak siswa secara keseluruhan untuk melakukan diskusi kelas, atau memberikan pengarahan umum, bertugas sebagai fasilitator baik secara klasikal atau individual.

Pendidikan Anak Usia Dini merupakan pendidikan yang menjadi gerbang awal memasuki pendidikan selanjutnya. Pendidikan sebaiknya dilaksanakan sedini mungkin sehingga pendidikan tersebut dapat menjadi investasi di masa depan. Pendidikan anak usia dini merupakan upaya pengembangan yang ditujukan untuk anak-anak sejak lahir hingga usia delapan tahun, dilakukan melalui penyediaan rangsangan pendidikan untuk mendorong pertumbuhan fisik dan psikologis sehingga anak-anak dapat bersekolah memasuki pendidikan lanjutan. Periode ini merupakan periode yang kondusif untuk mengembangkan berbagai kemampuan fisik, kognitif, linguistik, sosioemosional dan spiritual. Pada usia ini adalah zaman keemasan dimana lingkungan dapat mendorong dan merangsang semua aspek perkembangan anak secara optimal. Stimulasi atau rangsangan yang diberikan terhadap anak usia dini haruslah tepat.

Guru tidak hanya sekedar menyampaikan materi pelajaran kepada siswa namun harus merupakan seluruh kegiatan dan tindakan yang diupayakan oleh guru untuk terjadinya proses belajar sesuai dengan tujuan yang telah dirumuskan. Guru harus memiliki ketarmpilan mengajar, mengelola tahapan pembelajaran, memanfaatkan metode, menggunakan media, dan mengalikasikan waktu. Interaksi belajar mengajar, guru memegang kendali utama untuk keberhasilan tercapainya tujuan.

Belajar adalah suatu proses perubahan tingkah laku individu melalui interaksi dengan lingkungan. Slavin (2011) mengemukakan belajar merupakan usaha yang dilakukan seseorang melalui interaksi dengan lingkunganya untuk merubah perilakunya. Kegiatan belajar adalah perubahan perilaku yang relatif permanen pada diri orang yang belajar. Belajar adalah proses perubahan tingkah laku seseorang berdasarkan praktek.Artinya dalam belajar diharapkan perolehan pemecahan masalah. Belajar menurut Hill (2007) belajar terjadi disebabkan pengalaman yang menyebabkan perubahan relatif permanen dalam pengetahuan individu. Menurut (Good dan Brophy 1990), dimensi belajar mengacu pada cara pendekatan belajar dalam membuat tugas, belajar hapalan digunakan untuk mencoba mengingat informasi baru 
tanpa menghubungkan ide dengan objek yang sudah diketahui, dan belajar mengerti bertahan lebih lama.

$$
\text { Winkel (2004) }
$$

merupakan suatu aktifitas mental/ fsikis, yang berlangsung dalam interaksi dengan lingkungan, yang menghasilkan suatu perubahanperubahan dalam pengetahuan dan pemahaman, keterampilan, dan nilai sikap. Perubahan yang terjadi relative konstan dan berbekas.

Dalam mengembangkan pengajaran musik di PAUD, ada dua hal dasar yang perlu diperhatikan oleh seorang pendidik, yaitu dasar kependidikan dan dasar teoritis. Menurut Kamtini dan Tanjung (2005) beberapa hal yang perlu dipertimbangkan dalam menyediakan bahan lagu atau musik sebagai dasar kependidikan, antara lain: Pertama, aspek psikologis. Isi lagu atau musik benar-benar sesuai dengan jiwa dan alam pikiran anak; Kedua, aspek fisik. Tenaga, kekuatan, kemampuan dan keterampilan anak masih terbatas.Organ-organ tubuh seperti alat-alat pernapasan dan alat-alat suara masih dalam taraf pertumbuhan; Ketiga, aspek sosiologis. Penyediaan musik atau lagu tidak keluar dari lingkungan hidup anak: suka-duka dan pergaulan kanak-kanak sehari-hari, rasa kasih sayang dan sebagainya; Keempat, aspek paedagogis. Bahan musik yang disediakan dianggap dapat membantu perkembangan, pertumbuhan, kecerdasan dan keterampilan anak dalam segala hal menuju kedewasaan secara wajar; Kelima, aspek didaktis. Melodi harus sederhana. Langkah interval jangan terlalu sukar, sebaiknya jarak nada berdekatan tidak melampaui kuart. Ritme (rhythm) atau irama yang dipakai yang mudah saja, nada-nada yang digunakan cukup sampai nada $1 / 8$.

Selain itu, perlu diketahui, diperhatikan, dan dipertimbangkan karakteristik suara dan musik anak yang sesuai dengan aspek-aspek perkembangannya. Anak usia PAUD belajar berbicara dan bernyanyi dengan cara meniru apa yang mereka dengar dan meresponsnya serta mengekspresikannya dengan cara mereka masing-masing.

Dalam memilih lagu bagi anak usia PAUD, ada beberapa hal yang perlu diperhatikan. Menurut Palmer seperti dikutip Rachmi (2008) lagu yang dipilih untuk anak-anak prasekolah adalah lagu yang : (1) dapat mendorong anak untuk aktif terlibat dalam kegiatan yang diselenggarakan pendidik; (2) berhubungan dengan minat anak-anak; (3) berhubungan dengan dunia anak-anak; (4) memiliki melodi yang berisi frase-frase yang diulang-ulang sehingga mudah dipelajari dan diingat oleh anak-anak; (5) menekankan pada unsur-unsur ritmik, irama, dan aliterasi; (6) bila berupa rekaman dari berbagai versi lagu atau musik instrumentalia yang liriknya mudah untuk diganti dengan lirik yang baru ciptaan pendidik dan peserta didik; (7) anak-anak dapat diminta untuk menggantikan namanya sendiri, atau teman-temannya, atau saudara-saudaranya bila lagu tersebut menyebutkan nama orang.

Dengan karakteristik seperti itu, dalam memilih lagu untuk anak PAUD pendidik perlu memperhatikan karakteristik suara dan lagu anak usia PAUD. Lagu hendaknya dapat mengembangkan dan meningkatkan pengalaman musikal dan suasana hati anak dengan mengambil tema-tema yang kontras.

Derya Arslan (2015) menyatakan bahwa: salah satu kegiatan yang 
dilakukan dalam rangka meningkatkan kesadaran fonologis adalah menyanyikan lagu. Lagu adalah salah satu alat penting yang digunakan dalam pendidikan, terutama dalam pengajaran bahasa. Kemampuan berbicara serta bahasa anak sangat dipengaruhi oleh lagu yang dekat dengan lingkungan anak, tentunya lagu daerah merupakan salah satu media yang dapat digunakan oleh guru dalam mengembangkan kemampuan berbicara anak (Yetti, Anggraini, \& Hapidin, 2017)

Lagu kreasi Minangkabau merupakan lagu yang dibuat dan dikreasikan menggunakan bahasa minangkabau. Lagu daerah dapat diaplikasikan kepada anak usia dini adalah lagu yang disesuaikan dengan karakteristik anak, kebutuhan dan perkembangan anak. Sehingga tujuan utama perkembangan bahasa anak dapat berkembang secara optimal

Begitupun dengan proses pembuatan lirik di lagu-lagu Minang. Lagu Minang hanya judul untuk lagulagu dari Minangkabau atau Sumatera Barat. Karena pengaruh dialek, lagulagu Minangkabau sering disebut sebagai lagu-lagu Minang saja. Dari sini diketahui bahwa sebenarnya lagu Minang adalah sejenis lagu daerah bukan lagu rakyat (folk song). Lagulagu daerah mencerminkan normanorma dan nilai-nilai budaya Minangkabau.

\section{METODE PENELITIAN}

Metode penelitian ini adalah penelitian tindakan. Wijaya (2001) menjelaskan bahwa penelitian tindakan merupakan salah satu cara strategis bagi pendidik untuk memperbaiki dan / atau memperbaiki layanan pendidikan dalam konteks pembelajaran di kelas. Teknik pengumpulan data yang digunakan dalam penelitian ini adalah non test. Teknik non test yang digunakan untuk memperoleh data tentang pelaksanaan tindakan dan data kemampuan berbicara anak (variabel terkait) adalah observasi. Observasi yang digunakan adalah observasi partisipan, dimana pengamat berpartisipasi dalam kegiatan yang dilakukan oleh subyek yang diteliti atau diobservasi seolah-olah mereka adalah bagian dari mereka.

Perancangan intervensi / desain tindakan siklus penelitian ini menggunakan model Kemmis dan MC Taggart berdasarkan: (1) perencanaan, (2) tindakan / observasi, (3) refleksi. Teknik analisis data kuantitatif dan kualitatif. Analisis data kuantitatif disajikan dalam bentuk tabel dan grafik. Sedangkan analisis data kualitatif menggunakan metode Miles dan Haberman, yang terdiri dari tahap reduksi data, tampilan data dan verifikasi data (1992).

\section{HASIL DAN PEMBAHASAN}

Belajar adalah suatu proses perubahan tingkah laku individu melalui interaksi dengan lingkungan. Kegiatan belajar adalah perubahan perilaku yang relatif permanen pada diri orang yang belajar. Belajar adalah proses perubahan tingkah laku seseorang berdasarkan praktek. Artinya dalam belajar diharapkan perolehan pemecahan masalah. Dimensi belajar mengacu pada cara pendekatan belajar dalam membuat tugas, belajar hapalan digunakan untuk mencoba mengingat informasi baru tanpa menghubungkan ide dengan objek yang sudah diketahui, dan belajar mengerti bertahan lebih lama. Pada saat memasuki usia sekolah TK anak mulai memiliki kesanggupan untuk mengenal lingkungan dan sejarah budaya minangkabau sesuai dengan tahapan usia.

\section{Pra siklus}


Assesmen awal pada kemampuan mengenal sejarah budaya minangkabau anak melalui lagu kreasi minangkabau menunjukan bahwa masih banyak anak yang kemampuan mengenal sejarah budaya minangkabau. Berikut hasil Assesmen awal kemampuan anak dapat dilihat pada grafik di bawah ini :

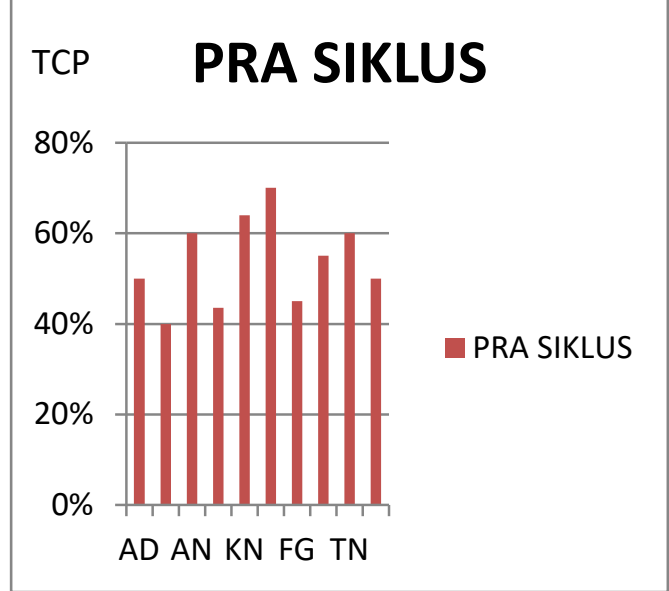

Graph 1: Pra-siklusHasil Kemampuan Mengenal Sejarah Budaya Minangkabau

Berdasarkan visualisasi grafik diatas menunjukkan bahwa masih rendahnya kemampuan mengenal sejarah budaya minangkabau, terlihat pada taraf penilaian belum muncul, dan mulai muncul sedangkan sering muncul dan konsisten masih sedikit anak yang mampu menceritakan sejarah budaya minangkabau yang telah di ceritakan oleh guru pada tahap penilaian ini. Dari data pra siklus menunjukkan nilai awal anak dilihat dari persentase skor awal sebagai berikut: AD 50\%, AL 40\%, AN 60\%, BB44\%, KN 64\%, RC 70\%, FG 45\%, $\mathrm{HH} \quad 55 \%$ TN $60 \%$, ZC $50 \%$. Sedangkan rata-rata persentase sekitar $54 \%$. Dengan demikian data yang menunjukkan persentase siswa TK kelas B pada pre-cycle yang memiliki persentase lebih tinggi dari rata-rata anak lain hanya sebesar 4 (empat) anak. Persentase tertinggi dari keseluruhan aspek tertinggi dari skor pra-siklus $70 \%$ dimiliki oleh Rc.
Berdasarkan data pengamatan padaprasiklus di atas, yang telah terpapar melalui data kualitatif dan kuantitatif, sehingga peneliti dan kolumnis menyimpulkan tindakan yang diperlukan dirancang dan diharapkan dapat meningkatkan kemampuan pengenalan sejarah budaya minangkabau bagi anak usia dini.

\section{Siklus I}

Selanjutnya peneliti memberikan tindakan berupa stimulasi menggunakan lagu kreasi minangkabau kepada anak usia dini. Pada proses kegiatan stimulasi lagu kreasi minangkabau ada beberapa tahapan kegiatan yang harus diperhatikan a) penyesuaian dengan tema yang sedang berlangsung, b) mendengarkan lagu yang akan dinyanyikan, c) bermain sajak lagu, d) bernyanyi diirimgi alat musik keyboard. Kelebihan yang dirasakan berdasarkan penelitian ini adalah anak sangat menyenangi proses kegiatan bernyanyi menggunakan lagu kreasi minangkabau sehingga peneliti menemukan berbagai hal yang sangat menarik dan menunjukkan peningkatan dalam pengenalan sejarah budaya minangkabau.

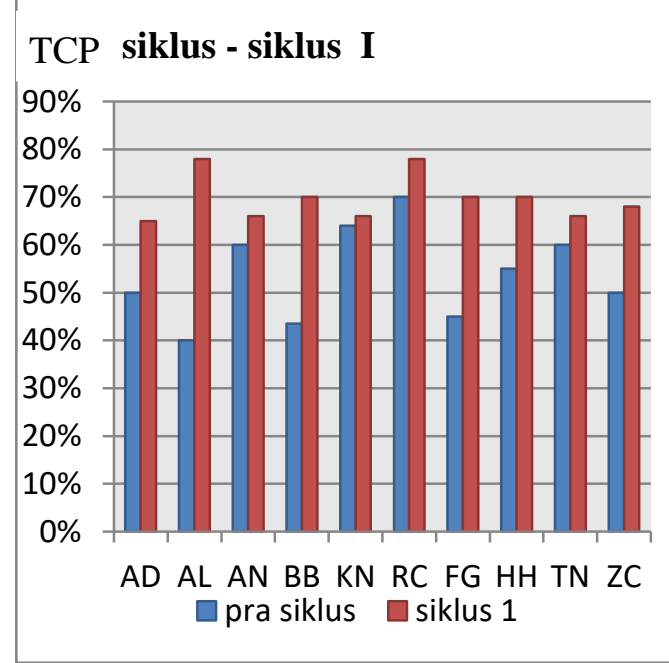

Graph 2: Grafik hasil kemampuan pengenalan sejarah budaya minangkabau 
Berdasarkan visualisasi grafis, hal ini menunjukkan peningkatan kemampuan yang dialami selama siklus 1 . Dari jumlah tersebut hanya 2 (dua) anak yang mencapai skor persentase minimal 75\% (TCP / level prestasi pembangunan), yaitu $\mathrm{Al} 78 \%$, Rc $78 \%$. Dengan kata lain, hanya $20 \%$ siswa yang mencapai peningkatan TCP sebesar $75 \%$ dengan kriteria menurut Mills sebesar $71 \%$. Dengan demikian persentase perbaikan yang dijelaskan di atas menunjukkan bahwa masih ada hal-hal yang perlu ditingkatkan untuk memaksimalkan pencapaian kriteria keberhasilan. Oleh karena itu, perlu diimplementasikan siklus kedua sehingga akan memaksimalkan pembelajaran dalam meningkatkan kemampuan pengenalan sejarah budaya minangkabau.

\section{Siklus II}

Pada proses kegiatan stimulasi anak melalui lagu kreasi minangkabau ada beberapa yang temuan, yaitu a) sikap anak, b) partisipasi anak. Temuan yang mengarah pada sikap anak yang muncul adalah : a) keterlibatan, yaitu saat bernyanyi, anak menunjukkan keterlibatan, walaupun terkadang ada anak yang juga tidak ingin terlibat namun dengan arahan guru pada akhirnya anak ikut menikmati permainan, b) rasa ingin tahu, yaitu saat anak bertanya tentang langkah langkah permainan serta rasa tidak sabar menunggu giliran bermain, dan c) minat anak, saat mengikuti proses kegiatan bernyanyi menggunakan lagu kreasi minangkabau sehingga anak dengan senang dan mudah mengenal sejarah budaya minangkabau. Hal Ini terlihat dari grafik Hasil Pra-siklus, siklus I dan Siklus II.

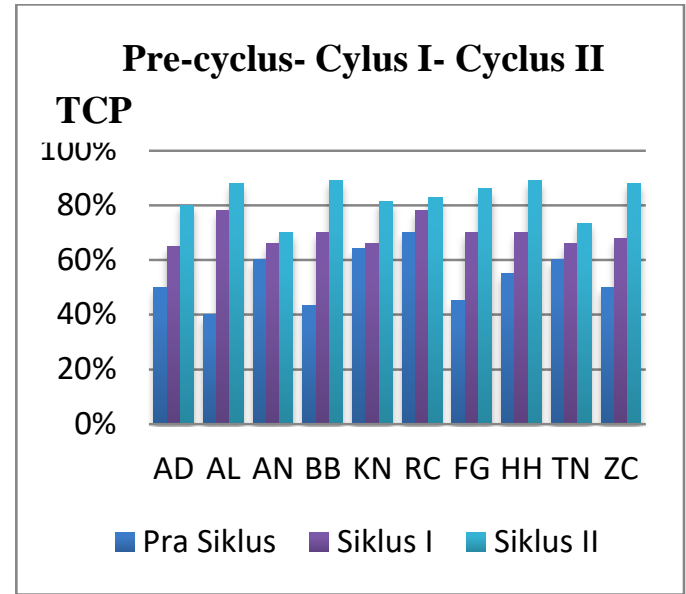

Graph 3: Grafik hasil Peningkatan kemampuan pengenalan sejarah budaya minangkabau

Berdasarkan grafik di atas dapat dijelaskan bahwa melalui lagu kreasi minangkabau dapat meningkatkan kemampuan pengenalan sejarah budaya minangkabau. Hal ini terlihat melalui persentasi Pra-siklus dalam lagu kreasi minangkabau menunjukkan 54\% pengenalana sejarah nya berkembang, sedangkan di siklus I mengalami peningkatan meskipun tidak signifikan dan belum sesuai dgn TCP yaitu hanya $69,70 \%$ sehingga peneliti harus merumuskan siklus ke II. Pada siklus II guru dan peneliti memperbaiki dari berbagai kekurangan yang terjadi pada siklus I. Setelah dilaksanakan siklus II peneliti memperoleh $82,74 \%$ sehingga lagu kreasi minangkabau baru dapat dikatakan berhasil dan tidak melanjutkan pada siklus berikutnya. Dari kegiatan tersebut peneliti memperoleh berbagai temuan baik proses dan hasil.

Temuan pada proses partisipasi anak dalam lagu kreasi minangkabau yaitu : a) peran serta anak, yaitu anak dalam melakukan kegiatan tampak senang mengikuti arahan guru, serta mampu menyelesaikan tugas tertentu dalam proses kegiatannya. Di sini dapat di lihat tanggung jawab anak serta rasa percaya diri anak mulai nampak, b) respon anak, yaitu anak dalam mengikuti kegiatan bermain 
sangat senang, c) Perhatian anak, yaitu saat guru menjelaskan dan memberi panduan atau langkah-langkah dalam bermain, anak antusias mendengarkan serta mengikuti apa yang disampaikan oleh guru.

Temuan berikutnya ialah pada proses tindakan Guru, saat mengikuti kegiatan yaitu : a) Fasilitator, yaitu guru menyediakan bahan dan media yang diperlukan selama proses kegiatan. Guru juga memberi stimulus yang dapat berpengaruh pada perhatian serta minat anak dalam mengikuti kegiatan. b) Motivator, yaitu guru dapat memberikan semangat pada anak saat mengerjakan tugas maupun memberikan penguatan pada anak saat belum berhasil mengerjakan tugas, guru pun dapat memberikan penghargaan saat anak berhasil dalam mengerjakan tugas. c) Evaluator, yaitu guru bertugas mengevaluasi seluruh proses kegaiatan belajar menjagar dan memberikan assesment terhadap hasil kegiatan belajar dan bermain anak.

Tujuan pembelajaran sejarah budaya minangkabauakan tercapai dengan baik jika pendidik mampumengaplikasikan metode dan media pembelajaran yang tepat dengan kebutuhan peserta didik. Metode merupakan alat untuk mencapai tujuan, hal ini berlaku baik bagi guru, dosen, pelatih, dan siswa. Makin baik metode itu, makin efektif pula pencapaian tujuan. Dengan memiliki pengertian secara umum mengenai sifat berbagai metode, baik mengenai kebaikanya akan lebih mudah untuk menetapkan metode yang akan dilaksanakan.

Di taman kanak-kanak, musik adalah salah satu wahana bagi anak untuk belajar mengungkapkan pikiran dan perasaan, baik sebagai perorangan maupun sebagai anggota kelompok. Kegiatan musik yang dilakukannya sendiri atau bersama-sama, dapat membantu anak memantapkan emosi, dan menggunakan emosi sebaikbaiknya. Menurut Yeni (2011), kegiatan musik dapat meletakkan dasar bagi perkembangan minat dan bakat musik anak selanjutnya. Perkembangan itu sendiri tidak terlepas dari sejauh mana anak memperoleh pengalaman musik secara langsung. Lagu adalah salah satu perwujudan bentuk pernyataan atau pesan yang memiliki daya menggerakkan hati, berwawasan citarasa keindahan, dan cita rasa estetika yang dikomunikasikan. Karena itu, lagu memiliki fungsi sosial. Kekuatan lagu pada fungsi ini dapat kita lihat dibidang pendidikan. Melalui lagu, kita membantu anak menumbuhkembangkan aspek-aspek seperti: intelegensi,sosial, emosi, dan psikomotor. Melalui lagu yang sesuai, anak dapat: (1) menambah perbendaharaan bahasa, berbuat kreatif, berimajinasi (segi intelegensi); (2) bermain bersama, mematuhi aturan permainan, tidak mementingkan diri sendiri (segi sosial); (3) menyalurkan emosi, menimbulkan rasa senang (segi emosi); dan (4) melatih otot badan, mengkoordinasikan gerak tubuh (segi psikomotorik).

Atas dasar itu pula, lagu dikatakan (1) bahasa nada, (2) bahasa emosi, dan (3) bahasa gerak. Bahasa nada, karena lagu dapat didengar, dinyanyikan, dan dikomunikasikan. Bahasa emosi, karena lagu dapat menggugah rasa semangat, kagum, atau haru. Bahasa gerak, karena lagu itu sendiri adalah gerak, tergambar pada birama (ketukan keras-lunak), pada pola irama (panjang pendek bunyi), dan pada melodi (tinggi-rendah nada), yang dapat memotivasi anak melakukan gerak jasmani. Sehingga lagu mampu mengembangkan bahasa verbal maupun non verbal bagi anak usia dini 
Dengan mengajak anak bernyanyi bersama, kita memberi anak pengalaman yang berharga lagi menyenangkan, yang dilakukan bersama-sama. Adapun perolehan bernyanyi yang diharapkan, adalah agar anak: (1) mendengar danmenikmati lagu; (2) mengalami rasa senang bernyanyi bersama; (3) mengungkapkan pikiran, perasaan, dan suasana hatinya; (4) merasa senang bernyanyi, dan anak dapat belajar bagaimana mengendalikan suara; (5) menambah perbendaharaan kosa-kata melaui lagu.

Dalam kreasi Minangkabau lagu bukan hanya menyanyikan lagu-lagu Minangkabau, tetapi lagu itu menciptakannya menjadi sesuatu yang menarik. Penggunaan musik dan gerak ketukan yang merupakan kesatuan harmonisasi yang indah, yang di dalamnya menyimpan makna dan informasi yang akan disampaikan melalui bahasa Minangkabau. Dengan maksud meningkatkan kemampuan berbicara Minangkabau terus menjadi ciri khas lokal dan masih dilestarikan keberadaannya oleh masyarakat Minangkabau itu sendiri, melalui pembuatan lagu Minangkabau.

Anak bernyanyi menurut cara dan gayanya sendiri, karena ia menyenanginya. Benar, kita dapat menyuruh anak bernyanyi dengan cara lain, yang menurut pendapat kita hasilnya akan lebih baik, umpamanya menyuruh anak melakukan latihan vokal dengan paksa, atau dengan latihan yang melelahkan. Maksudnya agar anak dapat meningkatkan mutu suaranya. Namun cara ini kurang bijak, karena dapat mengurangi rasa senang, rasa gembira anak bernyanyi. Akibatnya, bisa-bisa anak kurang menyukai musik, atau bernyanyi.

Karena bernyanyi memegang peran sangat penting dalam proses pembelajaran di PAUD, maka guru dituntut memiliki kemampuan Stimulasi bahasa yang akan diajarkan kepada peserta didik.

\section{SIMPULAN}

Sejarah budaya minangkabau sangat penting bagi perkembangan musik anak-anak dan pendidikan di waktu pengalaman TK mereka pada usia 5-6 tahun. Meskipun guru TK memiliki kemampuan terbatas dalam memberikan media yang menarikLagu daerah adalah lagu yang berasal dari kebudayaan, adat, istiadat dari suatu daerah. Dalam penerapan stimulasi bagi anak hendaknya yang paling dekat dengan lingkungan anak, sehingga lagu daerah adalah salah satu alternatif untuk mengembangkan kemampuan bahasa anak usia dini. Lagu kreasi Minangkabau merupakan lagu yang dibuat dan dikreasikan menggunakan bahasa minangkabau. Lagu daerah dapat diaplikasikan kepada anak usia dini adalah lagu yang disesuaikan dengan karakteristik anak, kebutuhan dan perkembangan anak. Sehingga tujuan utama pengembangan konsep sejarah budaya minangkabau tercapai.

\section{DAFTAR PUSTAKA}

Arslan, D. (2015). "First Grade Teachers Teach Reading With Songs, "Journal of Humanities and Social Sciences, 20.

Azhar, A. (2010). Media Pembelajaran. Bogor : Raja Grafindo.

C.P. Hill. (2007). Saran-Saran Tentang Mengajarkan Sejarah. Jakarta: Perpustakaan Keguruan Kementrian P Dan K.

Kamtini, \& Tanjung, H., W. (2005). Bermain Melalui Gerak dan Lagu di Taman Kanak-Kanak. Jakarta: Departemen Pendidikan Nasional 
Miles \& Huberman. (1992). Analisis data Kualitatif. (diterjemahkan Ole: Tjetjep Rohedi Rosidi). Jakarta: Universitas Indonesia.

Robert E., S. (2011). Educational Psycology. $5^{\text {th }}$ ed. Boston: Allyn and Bacon.

Thomas L., G \& Jere E., B. (1990). Educational Psychology. New York: Longman.

W. S. Winkel. (2004). Psikologi Pengajaran. Yogyakarta: media Abadi.

Wijaya, K \& Dedi, D. (2001). Mengenal Penelitian Tindakan Kelas. Jakarta: Indeks

Yeni, I. (2011). Metodologi Pengembangan Seni Musik Suara. Padang: Jurusan PGPAUD FIP Universitas Negeri Padang.

Yetti, Y., Anggraini, V., \& Hapidin, H. (2017). Improving Ability to Speak Mother Tounge Through Use of Minangkabau Creation. IJER - Indonesian Journal of Educational review. https://doi.org/10.21009/ijer.04.0 1.06

Rachmi, T. (2008). Keterampilan Musik dan Tari. Jakarta: Universitas Terbuka. 